\title{
EDITORIAL
}

\section{Legal transplants in contemporary Asia: Foreword}

\author{
Setsuo Miyazawa \\ Kobe University and University of California Hastings College of the Law
}

The term "legal transplant" refers to the movement of a rule or a system of law from one jurisdiction to another. The term has been widely used in studies of legal development and change since it was introduced by Allan Watson, a Scottish scholar in Roman law and comparative law, in $1974 .^{1}$ The jurisdiction in which the transplanted legal rule or legal system originated is usually called a "donor," while the jurisdiction in which the given legal rule or legal system is transplanted is usually called a "recipient."

When legal transplant in an Asian jurisdiction was analyzed, the donor was usually a non-Asian jurisdiction or organization. ${ }^{3}$ However, Japan has been engaging in several legal assistance activities in Asian jurisdictions since the mid-1900s, ${ }^{4}$ while there is an evaluation about China under President Xi Jinping that "Western donors now face competition from China, not only for economic development projects, but in legal development assistance, too." ${ }^{5}$ When I was involved in organizing sessions at the 4th Annual Meeting of the Asian Law and Society Association (ALSA) that was to be held at Osaka University in Toyonaka, Japan, on 13-15 December 2019, I thought that inter-Asian legal transplants might be a good topic and circulated the following call for papers on 6 June 2019:

Asia used to be receivers of legal transplants, but recently some Asian countries, most notably China and Japan, have appeared as donors of legal transplants. In such donor activities, national, scholarly, and practical interests are intertwined, and different ideas on "the rule of law" in general or the most appropriate system for the given issue compete with each other. Those who are interested in this topic are kindly requested to send me a 500-word abstract by July 15 .

Nine proposals were accepted and two sessions on legal transplant were held on 13 December 2019. Rob Leflar and Amy H. Shee kindly participated as discussants. This

\footnotetext{
${ }^{1}$ Watson (1974).

${ }^{2}$ I personally hesitate to use these terms. The term "donor" gives an impression that the donor has mainly a benevolent motive, while the term "recipient" gives an impression of total passivity. It is more realistic to assume that different actors on both sides have different interests and actively engage in a political process that ultimately produces or fails to produce a certain legal result. It would be more interesting and productive to analyze the process of legal transportation as such a dynamic political process. Indeed, all three papers in this symposium issue, particularly those by Erie and Ha and by Kaneko, describe such dynamic processes, including highly proactive involvement by the government and other members of the "recipient" jurisdictions. I once proposed to study such a process from a social-movement perspective See Miyazawa (2006), pp. 928-31. I use the terms "donor" and "recipient" here simply because they have been commonly used in previous studies.

${ }^{3}$ One of the most recent and interesting examples is Liljeblad (2019-20).

${ }^{4}$ Kuong (2018).

${ }^{5}$ Seppänen (2018), p. 105.
} 
symposium issue includes three of those papers, each of which has been extensively revised after the meeting and through the peer-review process of this Journal.

Aziz Ismatov, in "Do Hybrid Legal Systems Matter in Foreign Legal-Aid Programmes? Some Philosophical Aspects of Legal Aid in Uzbekistan as Provided by the Donor States," compares the relative effectiveness of donor activities by the three consecutive donor countries, namely the US, Germany (EU), and Japan, particularly within the hybrid structure of the Uzbek law, which bears many traces of the USSR legal system and an indigenous and informal Islamic law. Aziz states that while "ideas, values, and practices promoted by the US and, partly, EU legal-aid projects still lack adequate cultural compatibility and credibility with Uzbekistan's government and society," "Japanese legal-technical assistance/co-operation is fundamentally different" in that "it puts a specific emphasis on the mutual understanding of society, distinctive culture, and history," including a "soft and flexible" attitude regarding "human rights and democracy."

Matthew S. Erie and Do Hai Ha, in "Law and Development Minus Legal Transplants: The Example of China in Vietnam," present a case-study of the legislative process of the SEZ (Special Economic Zone) Bill in Vietnam that was initiated in 2014 and suspended in $2018 .^{6}$ Erie and Ha argue that "the most remarkable aspect of borrowing from the Chinese experience was the proactive involvement of the Vietnamese state in developing its SEZs" and that "the Vietnamese government received extensive technical support from Chinese experts." However, they describe that "[t]he SEZs Bill triggered considerable criticism" and "the most vocal criticism normally came from economists, including domestic, diasporic, and sometimes international experts." Finally, "[i]n May 2018, a month before the SEZs Bill was scheduled for passage, criticism against the Bill exploded," "demonstrations involving hundreds or thousands of people took place in major cities and provinces across the country," and "as a result, the SEZs Bill has been postponed indefinitely." After presenting hypotheses regarding positive and negative factors on the successful legal transplants from China, the authors conclude that "if China is to emerge as a successful contender in the law-and-development market, it will likely resort to other means, in addition to legal transplants, to secure its investments abroad," including

greater vertical integration of Chinese norms into international economic law and the building of cross-border transnational law, mainly in the form of inter-corporate agreements, international arbitration, and onshoring commercial disputes, each of which is formative of CLD [Chinese Law and Development].

Yuka Kaneko, in "Land-Law Reforms in Vietnam and Myanmar: 'Legal Transplant' Viewed from Asian Recipients," presents a very different paper: she strongly criticizes the reform of positive law by the recipient government based on legal transplants in general for its destruction of traditional rights based on "living law" that has existed among people in affected areas. She traces the process of the introduction of the concept of "land-use right" in Vietnam and the concept of "land-use right for cultivation" in Myanmar, their impact to weaken traditional perpetual right for cultivation and to increase the transferability of farm land, and the rise of resistance and disputes involving affected farmers, with an additional analysis of the failure or insufficiency of mechanisms to solve or prevent disputes. A wide variety of donors appear, including the World Bank, the Asian Development Bank, Japan, the United Nations, and the US, but the problem is not specific donors, but the introduction of positive law that ignores traditional living law. The author states that

\footnotetext{
${ }^{6}$ They also mention two previous examples of legal imports from China, namely the "land-use right" in the 1993 Land Law and the guiding case-law system introduced in 2015. Yuka Kaneko discusses them critically in her paper in this symposium issue.
} 
[n]ow, in the era of the contemporary "legal transplant," donors intervene while loudly advocating the protection of small farmers and customary law but, in fact, their legal designs are leading to the commercialization of farmland, through the freedom of disposal, land-expropriation law, vacant-land nationalization, and cityplanning law, which draws farmland into the land market.

She concludes the paper by arguing that

when the legislative processes of Asia and Africa are freed from the restraint of "legal transplant," it may be possible to save the self-contradiction of modern capitalist law from the constraint of belief in perpetual growth and social evolution, through which the human race is placing an excessive load upon the global environment.

Together, these papers present careful case-studies of inter-Asian legal transplants as well as a call for the recognition of living law as a source of law superior to positive law based on legal transplants. I trust that readers will enjoy and learn much from these papers.

\section{References}

Kuong, Teilee (2018) "Legal Assistance in the Japanese ODA: The Spark of a New Era." 5 Asian Journal of Law and Society 271-87.

Liljeblad, Jonathan (2019-20) “The Independent Lawyers’ Association of Myanmar (ILAM): Challenges Facing the Legal Transplant of International Expectations for a Bar Association into a Local Context." 43 Fordham International Law Journal 1133-60.

Miyazawa, Setsuo (2006) "How Does Culture Count in Legal Change? A Review with a Proposal from a Social Movement Perspective.” 27 Michigan Journal of International Law 917-31.

Seppänen, Samuli (2018) "Chinese Legal Development Assistance: Which Rule of Law? Whose Pragmatism?" 51 Vanderbilt Journal of Transnational Law 101-58.

Watson, Alan (1974) Legal Transplants: An Approach to Comparative Law, Edinburgh: Scottish Academic Press.

Cite this article: Miyazawa, Setsuo (2021). Legal transplants in contemporary Asia: Foreword. Asian Journal of Law and Society 8, 348-350. https://doi.org/10.1017/als.2021.41 